\title{
Introduction to the Law of the European Communities
}

\author{
Edited and further revised by Laurence W Gormley in co-operation with \\ P.J.G. Kapteyn and P. VerLoren van Themaat, editors of the Fifth Dutch Edition
}

Kluwer Law International is pleased to announce the publication in August 1998 of the longawaited Third Edition in English of Introduction to the Law of the European Communities.

It incorporates the Fifth Dutch Edition, published in 1995, and has been further revised and updated by Laurence Gormley, in co-operation with the editors of the Dutch Edition, to take account of developments up to the spring of 1998. It adopts 'From Maastricht to Amsterdam' as its central theme and provides a definitive examination and analysis of developments in the whole field of European Community law, including legal aspects of the Second and Third Pillars.

This new edition presents exhaustive coverage of the institutional, procedural and substantive law aspects of European Community law, including a full examination of the historical, political and economic background, and assesses these issues in the light of the move towards economic and monetary union. The book therefore provides an authoritative and up-to-date reference work for legal practitioners, both professional and academic, which will enable them to understand clearly the complex nature of European Community law and the interaction between its various elements.

This impressive work has become widely accepted as a standard source of reference on the subject. We are pleased to announce that, in addition to the standard hardback edition for the professional and library markets, we will also be publishing a special Student Edition in paperback. Inspection copies of this edition will be available on request to all professors and teachers of EC law who wish to assess the suitability of the book as required course material.

\begin{tabular}{|c|c|c|c|}
\hline \multirow[t]{2}{*}{1.} & The genesis of the European & VI. & Administration of justice \\
\hline & $\begin{array}{l}\text { Communities and the accession of } \\
\text { other European countries }\end{array}$ & VII. & $\begin{array}{l}\text { The establishment of the internal } \\
\text { market: the freedoms }\end{array}$ \\
\hline \multirow[t]{2}{*}{ II. } & $\begin{array}{l}\text { General aspects of the European } \\
\text { Communities and the European }\end{array}$ & VIII. & $\begin{array}{l}\text { The competition policy of the } \\
\text { European Community }\end{array}$ \\
\hline & Union & IX. & Economic, monetary and social policy \\
\hline \multirow[t]{3}{*}{ III. } & The basic principles of the European & $X$ & Horizontal and flanking policies \\
\hline & Community, and citizenship of the & $\mathrm{XI}$. & Sectoral policies \\
\hline & European Union & XII. & Extemal relations \\
\hline IV. & Institutional structure & & Epilogue \\
\hline V. & Policy-making and administration & & Index \\
\hline
\end{tabular}

Publication date: August $1998 \cdot$ No. of pages: $1000+$

ISBN: 90-41 1-9667-6 (Hardback) ·90-411-9666-8 (Student Paperback)

Price: f85.00/US\$135.00 / NLG250.00 (Hardback) - £32.00/US\$51.00 / NLG94 .00 (Student Paperback)

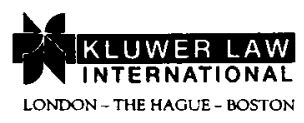

NETHAS 


\section{Cornelius van Bynkershoek: His Role in the History of International Law}

by Kinji Akashi

The primary aim of this work is to present a critical analysis of the writings of Cornelius van Bynkershoek (1673-1743), an eminent Dutch jurist known traditionally as a 'positivist', in the history of international law. However, it goes beyond an analysis of the 'classics' per se and attempts to clarify some basic questions concerning the history of international law, such as the relationship between legal doctrine and state practice, and the re-consideration of methodological differences among historical figures like Grotius, Pufendorf and Vattel. In addition to these questions, the work also covers some fundamental problems of international law in general, such as the meaning of positivism and positive law, and the function of reason.

To discuss these issues, the work is divided into three main parts. The construction of Bynkershoek's general theory of the law of nations is covered in the first part. The second offers an overview and analysis of the contemporary practice relevant to his theories on the laws of neutral commerce. The final part discusses the 'genealogy' of Bynkershoek's works, namely his relation to Grotius and to his later generations of publicists.

KLUWER LAW INTERNATIONAL, THE HAGUE

JULY 1998, HARDBOUND, PAGES: 224

ISBN: 90-411-0599-9

PRICE: NLG $155.00 /$ US $\$ 84.00 /$ GBP 53.00

\section{Law, Ethics and the Visual Arts Third Edition}

by John Henry Merryman, Albert E. Elsen, Stanford University, CA, USA

What happens when the art world encounters the law and vice versa? This book describes these collisions with a critical eye through a combination of primary source materials, excerpts from professional and art journals, and extensive textual notes. Topics analysed include

- the fate of works of art in wartime.

- the international trade in stolen and illegally exported cultural property,

- artistic freedom,

- censorship and state support for art and artists,

- copyright,
- droit moral and droit de suite,

- the artist's professional life and death,

- collectors in the art market.

- income and estate taxation,

- charitable donations and works of art, and ant museums and their collections.

Law, Ethics, and the Visual Arts is unique in its description of the origins and development of major areas of art and practice; its analysis of international problems, applicable public and private international law, and different national approaches to similar problems; and its critical evaluation of the implications of laws, legal decisions, and art world practices. The authors are recognised experts in the field who have defined the canon in many aspects of art law.

Art world professionals, including practising and academic lawyers, trusts and estate lawyers and others dealing with art as an asset, those in the art trade, art administrators, the museum trustees and staff, art historians, archaeologists, and ant collectors will appreciate the unmatched features of Law, Ethics, and the Visual Arts and find it of great value in their work.

KLUWER LAW INTERNATIONAL, THE HAGUE

AUGUST 1997, HARDBOUND, PAGES: 1072

ISBN: 90-411-0697-9

PRICE: NLG 500.00/ US $\$ 270.00 /$ GBP 170.00

Please contact our office at the following address or order from your bookseller:

\section{For Europe and Rest of World}

Order Department, Kluwer Law International,

Distribution Centre, PO Box 322 ,

3300 AH Dordrecht. The Netherlands

Tel: + 31786546454

Fax: +31786546474

email: sales akli.wkap.n!

Tatt t.men nann 963955 (UK customers only)
For USA, Canada, South and Central America

Order Department, Kluwer Law International,

675 Massachusetts Avenue. Cambridge, MA 02139, USA Tel: (617) 3540140

Fax: (617) 3548595

email: sales@kluwerlaw.com 


\section{Liber Amicorum Professor Ignaz Seidl-Hohenveldern in Honour of his 80th Birthday}

edited by Gerhard Hafner, Gerhard Loibl, Alfred Rest, Lilly Sucharipa-Behrmann, Karl Zemanek

This Liber Amicorum is dedicated to one of the most outstanding international lawyers, Professor Seidl-Hohenveldern, to celebrate his eightieth birthday. He is known throughout the academic world for his profound contributions to the theory and practice of international law. Moreover, he has acted as arbitrator in a number of international cases and was President of the UN Conference on State Succession in respect of State Property, Archives and Debts.

The contents of the Liber Amicorum reflect the broad activities of Professor Seidl-Hohenveldern, both in his academic and practical work. The contributions cover the fields of international public law, international private law, international economic law, international human rights law, international environmental law and European law. The contributions from well-known authors from all parts of the world display an interesting and valuable spectrum of the current state of the law. Thus, a wide range of different topics of international law is covered and different positions on developments in recent years are discussed.

\section{KLUWER LAW INTERNATIONAL, THE HAGUE JUNE 1998 \\ HARDBOUND \\ PAGES: 912 \\ ISBN: 90-411-1024-0 \\ PRICE: NLG 370.00 / US\$200.00 / GBP 126.00}

Please contact our office at the following address or order from your bookseller:

For Europe and Rest of World

Order Department, Kluwer Law International,

Distribution Centre, PO Box 322 .

3300 AH Dordrecht, The Netherlands

Tel: +31786546454

Fax: +31786546474

email: sales @kli.wkap.n!

Toll free: 0800963955 (UK customers only)

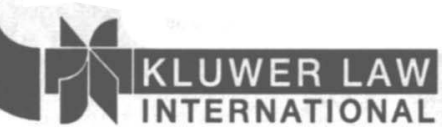

For USA, Canada, South and Central America Order Department, Kluwer Law International.

675 Massachusetts Avenue, Cambridge, MA 02139, USA Tel: (617) 3540140

Fax: (617) 3548595

email: sales@kluwerlaw.com 


\title{
Wie zal de Opvoeders Opvoeden?
}

\author{
Kindermishandeling en het Recht van het Kind \\ op Persoonswording
}

\author{
JAN C.M. WILLEMS
}

In Nederland bestaat een, in transgenerationele zin, discriminatoir privacysysteem dat kindermishandeling feitelijk toelaat en er geen effectieve bescherming tegen biedt. Dit gebeurt op zodanige schaal en met zulke verstrekkende individuele en maatschappelijke gevolgen dat er voldoende aanleiding is te spreken van een situatie van ernstige en passief-systematische mensenrechtenschendingen. In dit boek wordt bepleit deze situatie te keren door - in navolging van het Verdrag inzake de rechten van het kind - de persoonswording van kinderen te zien als verantwoordelijkheid van de ouders, maar zeker ook van de staat en deze verantwoordelijkheid waar te maken door een structurele en geïntegreerde preventieve benadering van opvoedingsproblematiek. Deze benadering vergt nieuwe maatschappelijke voorzieningen die op zijn minst een vangnet waarborgen in opvoedkundige risico-situaties. Het 'screenen' van mogelijke risico-situaties kan op nietstigmatiserende wijze geschieden op basis van een in dit boek geschetst drieechelonsmodel.

De Nederlandse overheid is tot hernieuwing van de wetgeving en beleidsinitiatieven op dit gebied verplicht, niet alleen op grond van het genoemde Verdrag maar ook in het licht van het gegeven dat in een rechtsstaat een voortdurende situatie van grove en grootschalige schendingen van fundamentele mensenrechten niet kan worden geduld.

Het boek integreert recente inzichten op mensenrechtelijk, psychologisch en pedagogisch gebied en bevat zowel een schat aan documentatie als een uitgebreid literatuuroverzicht. Het wordt optimaal toegankelijk gemaakt door een gedetailleerde inhoudsopgave, een auteursregister en een trefwoordenindex.

Jan C.M. WILLEMS is als universitair docent in het recht verbonden aan de vakgroep Internationaal en Europees Recht van de Universiteit Maastricht.

ISBN 90-6704-106-8

1200 pagina's, gebonden prijs $f$ 150,-

T.M.C. Asser Press, Postbus 30461, 2500 GL Den Haag Tel.070-3420300; Fax 070-3420351; E-mail Press@asser.nl 


\section{"

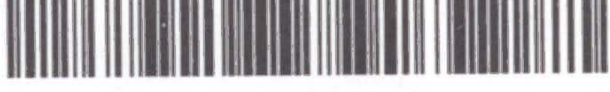

0165-070X(1998)45:3;1-G 